Discussion Paper No. 07-023

Apprenticeship Training in Germany Investment or Productivity Driven?

Thomas Zwick

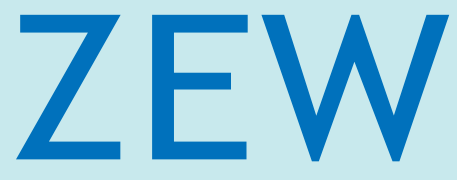

Zentrum für Europäische Wirtschaftsforschung $\mathrm{GmbH}$

Centre for European

Economic Research 
Discussion Paper No. 07-023

\title{
Apprenticeship Training in Germany - Investment or Productivity Driven?
}

\author{
Thomas Zwick
}

Download this ZEW Discussion Paper from our ftp server:

ftp://ftp.zew.de/pub/zew-docs/dp/dp07023.pdf

Die Discussion Papers dienen einer möglichst schnellen Verbreitung von neueren Forschungsarbeiten des ZEW. Die Beiträge liegen in alleiniger Verantwortung der Autoren und stellen nicht notwendigerweise die Meinung des ZEW dar.

Discussion Papers are intended to make results of ZEW research promptly available to other economists in order to encourage discussion and suggestions for revisions. The authors are solely responsible for the contents which do not necessarily represent the opinion of the ZEW. 


\section{Non Technical Summary}

The German dual apprenticeship system came under pressure in recent years because enterprises were not willing to offer a sufficient number of apprenticeship positions. A large theoretical literature argues that in Germany firms are willing to invest in apprenticeship training, i.e. to incur net costs during the apprenticeship period. On the basis of the specific institutional situation, firms have the opportunity to re-earn the net-costs after apprentices received their diploma and stayed in the firm. Important arguments are a high share of apprentices staying in firms, market power of firms and information asymmetries that allow firms to pay a wage below the productivity for "home-grown" skilled employees. It might be therefore argued that the gap on the apprenticeship market increased because the German firms are less willing to incur net apprenticeship costs (an indication for investment orientation) and instead increasingly try to cover the training costs already during the time before the apprentice got his or her diploma (an indication for productivity orientation).

Until now there is no representative evidence on the investment versus productivity orientation of German firms when it comes to their decision to offer apprenticeships. So far only the net costs of specific training professions have been calculated on the basis of cross section interviews. Hereby training firms have been directly asked on their costs and benefits while non-training firms had to indicate their potential costs and benefits. This approach is more prone to measurement error than indirectly estimating costs and benefits on the basis of representative firm profit regressions. This paper, therefore, investigates for the first time if German enterprises on average indeed incur net costs during the apprenticeship period including data from firms with and without apprentices. This is done by calculating if the impact of (an increase in) the share of apprentices on contemporary net revenues minus wage costs is negative. A positive contemporaneous impact is interpreted as productivity orientation. If an increase in the share of apprentices decreases contemporaneous profits per head (and increases lagged profits per head), this is interpreted as investment orientation.

The paper uses the representative linked employer-employee panel data of the IAB (LIAB) and takes into account possible endogeneity of training intensity and unobserved heterogeneity in the profit estimation by employing panel system GMM methods. An increase in the share of apprentices in the years 1997-2003 had neither a contemporary nor a lagged effect on profits per head. This is interpreted as a first indication that indeed most establishments in Germany do not invest more in apprentices during the apprenticeship period than the apprentices' productivity effect. 


\title{
Apprenticeship training in Germany - investment or productivity driven?
}

\author{
Thomas Zwick* \\ Centre for European Economic Research (ZEW), Mannheim \\ zwick@zew.de
}

April 2007

\begin{abstract}
The German dual apprenticeship system came under pressure in recent years because enterprises were not willing to offer a sufficient number of apprenticeship positions. A frequently made argument is that the gap could be closed if more firms would be willing to incur net costs during the training period. This paper investigates for the first time whether German enterprises on average indeed incur net costs during the apprenticeship period, i.e. if the impact of an increase in the share of apprentices on contemporary profits is negative. The paper uses the representative linked employer-employee panel data of the IAB (LIAB) and takes into account possible endogeneity of training intensity and unobserved heterogeneity in the profit estimation by employing panel system GMM methods. An increase in the share of apprentices has no effect on profits. This can be interpreted as a first indication that most establishments in Germany do not invest more in apprentices than their productivity effects during the apprenticeship period.
\end{abstract}

\footnotetext{
* I thank Friedrich Breyer, Wolfgang Franz, Nicole Gürtzgen, Jens Mohrenweiser, and Alexander Spermann for important comments, Stefan Listl for support in the literature survey and Diliana Stoimenova for able research assistance. I am also grateful to the Forschungsdatenzentrum in der Bundesagentur für Arbeit in Nuremberg - and here especially to Peter Jacobebbinghaus - for being helpful with accessing the LIAB data. This research has been funded by the German Science Foundation (DFG) and has been conducted in close co-operation with my colleagues from the DFG research group "Heterogene Arbeit: Positive und normative Aspekte der Qualifikationsstruktur”.
} 


\section{Introduction}

The German apprenticeship system is stuck in a deep crisis. Since 2002 the demand for apprenticeship positions permanently exceeded their supply (see figure 1). While Eastern Germany traditionally exhibits a backlog of such positions, their demand in Western Germany since 2003 has, for the first time in years, once again risen above the available number of apprenticeship jobs (see figures A1 and A2 in the appendix).

Figure 1: Development of supply of and demand for apprenticeship positions in Germany

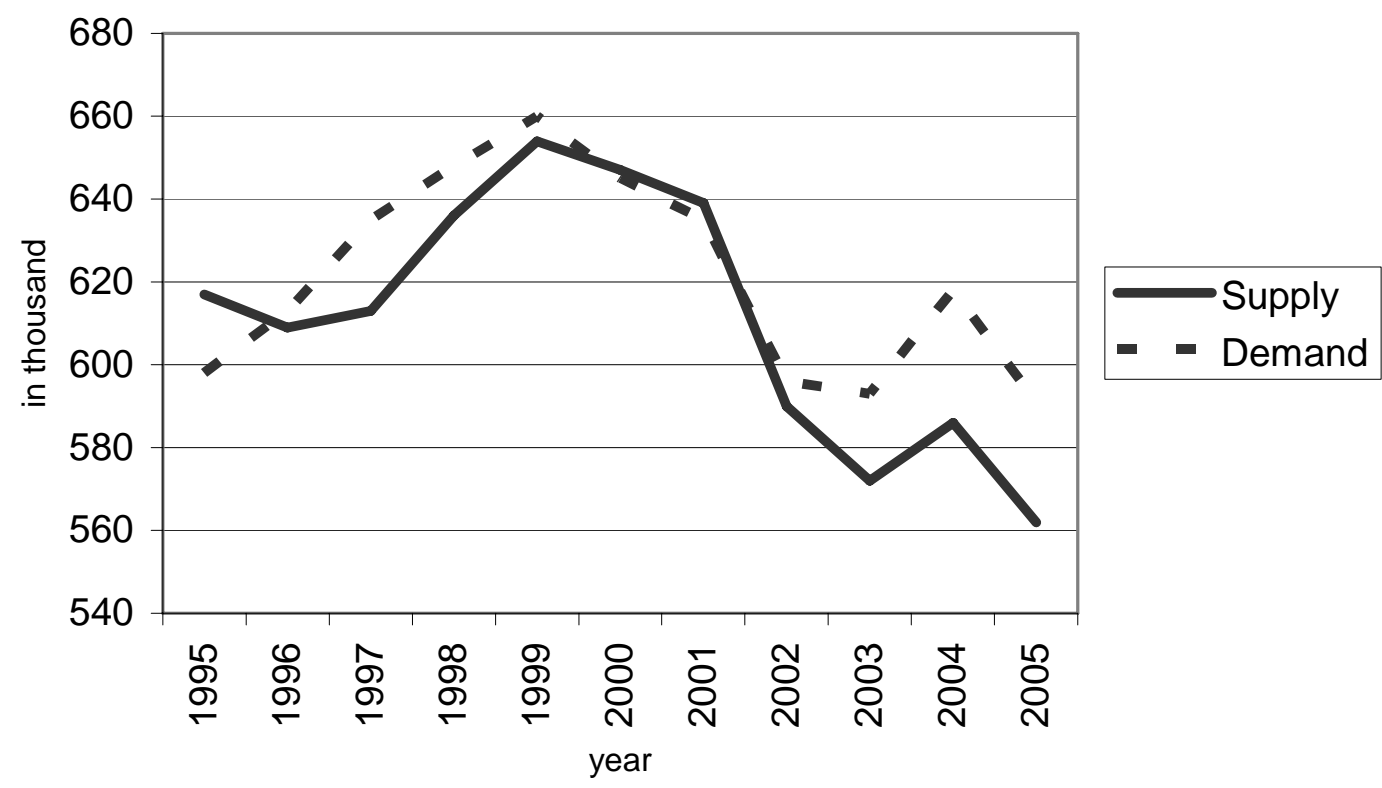

Source: Institut der deutschen Wirtschaft (2006), own illustration

A frequent reaction to the apprenticeship gap is the complaint that the firms do not invest enough in training apprentices. In this regard, it is usually argued that the apprentices' wages frequently lie above their productivity during their training period. This means, however, that companies have to retrieve the positive net investment costs after the graduation of the apprentice. This might be a problem especially if the shares of the apprentices who stay at their training firms are low or whether the labour market situation does not allow to pay a lower wage for skilled employees trained in-house (Smits und Zwick 2004; Wolter et al.. 2006). An important empirical question therefore is whether German firms do invest in apprentices during their training period, i.e. whether they have net costs that have to be recovered after the graduation of the apprentice. 
A first indication that net investment costs during the apprenticeship period are indeed an important obstacle for an increase in apprenticeship training is that according to the IAB establishment panel $2004^{1}$, the most important reasons for not conducting apprenticeship training were: „We cannot retain the apprentices after the end of their apprenticeship“ and „Self-conducted apprenticeship training is too laborious/expensive“. By contrast, reasons such as „We meet our requirements by hiring qualified staff“ or „We would like to offer apprenticeship training but no appropriate applicants are available“ were not mentioned as widely. This paper therefore tries to assess whether there are indeed net investment costs during the apprenticeship training - in other words, whether the impact of apprentice share on the contemporaneous profit of the firm before they graduate is negative.

Beicht et al. (2004) calculate that there are net costs of apprenticeship training between 30 and 70\% of the total training costs in Germany while Wolter et al. (2006) show that in the majority of Swiss firms with apprentice training, productivity is at least equal to apprentices' wages. The potential apprenticeship training costs of firms that do not offer that kind of training are markedly higher than the feasible productivity gain by apprenticeship training. Accordingly, the non-training firms would have to accept higher losses during apprenticeship training if they were to carry out such training. These cross section approaches have the disadvantage that they include subjective estimations of costs and benefits that may be biased by measurement errors ${ }^{2}$ and by social desirability.

In order to measure the impact of apprenticeship training on company performance, it is possible to compare the apprentices' productivity and wages. In the literature usually the contributions of the different qualification groups to a company's productivity and their shares to the wage costs are calculated separately. Hellerstein et al. (1999) and Galindo-Rueda and Haskel (2005) compare, for example, in non-linear panel regressions the marginal productivity of different employee types with their relative wages. $^{3}$ A higher positive share on productivity than the share on relative wages by a certain qualification group is interpreted as rent extraction by the firm from this

\footnotetext{
${ }^{1}$ This is a descriptive evaluation of item 84 of IAB Betriebspanel 2004, concerning firms that, in spite of being authorised to carry out apprenticeship training, do not offer apprenticeship positions.

${ }^{2}$ In both studies for example apprentices' benefits are calculated from benefits indicated by the respondent separately for typical unskilled and skilled activities and the share of activities the apprentices usually work as a substitute for unskilled and skilled employees in the firm.

${ }^{3}$ Please note that these studies do neither include apprenticeship shares nor German data.
} 
qualification group. A problem with this approach is, however, that the wage and productivity equation have to be equally specified and the results may be strongly influenced by the specification choice.

This paper makes two main contributions to the literature on the impact of apprenticeship training to the profitability of enterprises. It presents - to my knowledge for the first time - evidence based on representative and objective establishment data and it estimates the contribution of the share of apprentices on establishment profit directly in a profit estimation. Here the negative impact of a bigger share of apprentices on aggregate productivity is compared with their reduction of the average wage sum. Moreover, it is possible with the help of panel estimation techniques to account for the endogeneity in the composition of the qualification structure in the profit function as well as the unobservable time-invariant heterogeneity of firms. Finally, a number of further determinants of profits can be introduced to the estimation.

This paper is structured as follows. The next section discusses the determinants of the demand for apprentices and their impact on profits. Subsequently, the estimation strategy of the paper is presented. The fourth and the fifth section describe the data and the estimation results. The last section interprets the findings and their implications.

\section{Literature and Theoretical Background}

When asked about the crucial motives for apprenticeship training in their own firms, company owners often point out the social responsibility, the positive effects on the company's image, or the company's tradition in apprentice training (Sadowski, 1980; Stalder 1999; Niederalt et al. 2001; Schweri et al. 2003). In contrast, empirical studies show that the concrete decision for apprenticeship efforts mainly depends on the company owner's individual cost-benefit-calculation (Wolter et al. 2006).

According to the so-called „Warehouse Model“ (Backes-Gellner 1992, 1995) the optimal number of apprentices is derived from calculating the costs of in-house training and the costs of adoption of workers trained elsewhere. Thereby it is assumed that both the shortfall and the excessive number of own apprenticeship trainees lead to opportunity costs. The decision to provide apprenticeship training in the own firm critically depends on whether the firm's owner expects the training costs to be covered during training by means of the apprentice's own productivity (productivity orientation, Lindley, 1975; 
Neubäumer, 1999) or after the training through remuneration being lower than the staying former graduate apprentice’s productivity (investment orientation).

Empirical studies show that apprentices' contributions to productivity during their apprenticeship period in most firms cover and even go beyond the costs of training (Wolter et al. 2006). This means that the productivity of the apprentice covers the apprentice's wage, the trainer's wage, the acquisition and preservation costs for material, instruments and infrastructural facilities as well as for other costs.

Based on Becker's theory of human capital (Becker, 1964), a number of models were established that motivate an investment orientation that allows net investment costs during the apprenticeship period. Ex post, the net investment costs for training can be profitable for the firm if the personnel trained in-house, whose productivity is higher than the wage, is employed in the training firm (Acemoglu and Pischke, 1998,1999a,b; Booth and Zoega, 2004). A lower wage than their productivity for the skilled employees can be justified by a number of arguments that focus on labour market imperfections

First of all, apprenticeship training may mainly be industry-specific or rather firmspecific (Becker, 1964). This means that the apprentice has a much smaller productivity at other potential employers and this gives the training firm a favourable bargaining position (Acemoglu and Pischke, 1999; Smits and Stromback, 2001). This argument is weak in the German context because most qualifications are rather standardised, objectively tested and easily transferable to other firms in the same sector (Zwick 2001; Stevens, 2004).

A further argument for a profit contribution of own apprentices after the end of their traineeship is that apprentices prefer to stay in their home region (Niederalt et al., 2001). Remunerations below the productivity level are therefore possible as long as they are not lower than elsewhere considering the opportunity costs for mobility (Harhoff and Kane, 1997; Euwals and Winkelmann, 2001).

Also, asymmetric information with regard to the contents of training programmes can be considered as important for wage reductions. When external firms cannot precisely assess the specific training in a firm, there is an incentive to provide also general training contents. Hence, the result is a higher productivity of the own apprentices which is not compensated by an equivalent wage raise (Chang and Wang, 1996; Katz and Ziderman, 1990; Smits and Stromback, 2001). The above described 
mechanism seems to be not particularly relevant for Germany because of the high transparency of the training contents (Smits and Zwick, 2004; Niederalt et al., 2001).

Asymmetric information on the specific apprentice's skills is another argument. Apprenticeship training providers are aiming at retaining a highly productive apprentice in the own firm. Their information advantage over other firms is utilized by firing the less productive apprentices. External firms cannot assess the real potential of a newly-trained apprentice and are thus not willing to pay the full wage for these (Elbaum and Singh, 1995; Franz and Soskice, 1995, Acemoglu and Pischke, 1998).

Altogether, there is neither theoretical nor empirical consensus with regard to the extent to which the demand for apprentices in Germany is influenced by the willingness of the firms to invest in apprentices (Schwerdt and Bender, 2003, Dustmann and Schönberg, 2004). It is therefore unclear whether firms pursue a productivity or an investment oriented apprenticeship training policy. The current paper examines for the first time for Germany whether the apprenticeship training intensity influences the contemporary and the future profit per capita. It hereby assesses whether the German firms on average incur net investment costs during the apprenticeship period or not.

In a production-oriented firm, a higher share of apprentices increases profits. On the contrary, for investment-oriented firms a higher share of apprentices reduces contemporary profits. It can be positive in the long-run, however, to increase the share of apprentices whether it is possible to keep the apprentices in the firm and pay them a wage below their productivity. Correspondingly, the relation between the share of apprentices and contemporary profit is an indicator for an orientation towards production or towards investment.

We also include the share of other employee groups, e.g. different qualification groups in the profit function. This can be motivated by labour market inflexibilities, i.e. in this case by dismissal protection. While the firms can directly affect their share of apprentices, especially shrinking firms may face an inefficient composition of staff because employees cannot be replaced and laid off at will (Berthold and Fehn, 1998). Another reason for inflexibilities and an inefficient composition of the workforce may be a lack of suitably skilled job applicants (Kölling, 2002). As a consequence, some firms might not be at their profit optimal employee mix and an increase of the share of a particular employee groups would boost profits. Further personnel characteristics that can 
play a role with regard to profits is the share of foreign nationals (Zimmermann, 1998), as well as the average age and the average tenure (Lazear, 1981).

Classical explanation factors for profits are the market size and the (international) competitiveness (Fletcher, 2001; Gale, 1972). These are taken account of by the share of exports (Abel and Blanchard, 1986). Another important factor may be investments. However, in contrast to the previously mentioned variables it is not clear whether high investments boost profits or whether high profits enhance the investment affinity. In addition, it is well-known that establishments with works councils may be more profitable or at least have a higher productivity (Addison et al., 2004; Zwick, 2004b). Finally, East German firms are notoriously less profitable than their West German counterparts.

For the following estimation it is important to note that besides the differentiation in different sectors, industries and firm sizes, further potentially important factors cannot be observed. The quality of industrial relations or cyclic fluctuations in demand, for example, can also be determinants for the firm's profits while this cannot be directly controlled in our regressions.

\section{Empirical Specifications}

In this paper the impact of the share of apprentices on profits is examined. Besides the qualification structure of employees, further relevant determinants of the firm's profits are taken account of. The profit function that is to be estimated is specified as follows:

$\pi_{i t}=\alpha+\beta \cdot x_{i t}^{\prime}+\gamma \cdot u_{i}^{\prime}+\delta_{i}+\varepsilon_{i t}$,

where $t$ is a time indicator, $i$ is an establishment indicator, $\pi_{i t}$ is the profit per capita, and $x$ is a vector of time variant explanatory variables. The vector $u$ represents (practically) time invariant explanatory variables. Finally, $\delta$ denotes the unobservable time invariant factors and $\varepsilon$ stands for the normally distributed error term with expectance value of zero.

As a first step the profit functions of the firm are pooled, i.e. they are estimated as a cross section regression including observations from different years. That increases the number of observations, it also means that a firm that appears in several years is seen as a separate observation unit each time, however. Moreover, an estimation bias can occur in 
that specification because of the unobserved firm heterogeneity, i.e. most firms have unobserved characteristics that influence both the firm's profits and the share of apprentices. Examples are the quality of industrial relations or the innovation pressure that a firm faces. Here, the influence of a large share of apprentices on profits is upward biased whether good industrial relations lead to higher profits on the one hand and to higher training endeavours on the other hand. A further source of estimation bias is the possible endogeneity of the share of apprentices and other explanatory variables. It is possible that firms alter their qualification structure simultaneously with profits or that both are influenced by exogeneous shocks such as a positive trend in demand. It is conceivable, for example, that higher profits are a consequence of good personnel management and this also goes along with relatively high apprenticeship training efforts. In contrast, a relatively low profit might be a signal for a structural labour costs problem the establishment might try to solve by substituting skilled workers by apprentices..

Time invariant unobserved heterogeneity can be avoided by estimating the model in first differences or, in other words, by explaining the change in profits from one year to the next by means of a change in the composition of employer qualification and other covariates. As a second step, the profit functions are therefore estimated as a so-called Fixed Effects Regression, i.e. in first differences:

$\Delta \pi_{i t}=\beta \cdot \Delta x_{i t}^{\prime}+\varepsilon_{i t}$

Endogeneity of the explanatory variables can be removed by an instrumental variable regression. It is convenient, in this respect, to use GMM estimations with internal instruments, i.e. other moments of the same variable (Zwick, 2004a; Hempell, 2006). More precisely, the first differences of the explanatory variables are instrumented here by the levels of the lagged variables. We have to use lags $t-2$ if the variables are potentially endogeneous and lags $t-1$ if they are predetermined. We argued above that investments might be predetermined, i.e. profits in the last period have an impact on contemporary investments while we assume that all other time variant covariates are potentially endogeneous. The prediction power of the internal instruments could be small, however, given the only minor changes in the qualification structure of the employees from one 
year to another, for example. That could evoke biases in the GMM Estimator in first differences (Blundell and Bond, 1998).

Therefore we prefer the so-called System GMM Estimator of Arellano and Bover (1995). Here, the differences are instrumented again with lagged levels as internal instruments. Simultaneously the levels of the covariates are instrumented by adequate lagged differences. The main advantage of this approach is that besides the temporary differences, also differences among firms in levels are taken account of in the estimation. That improves the information used in identifying the effect and usually enhances the precision of the estimator. A necessary condition for the System GMM Estimator is that the correlations between the unobserved fixed effects and the covariates remain constant over time (Arellano and Bover, 1995). The profit estimations are carried out with the help of a two-step method under the application of Windmeijer's adjustment process for variances (Windmeijer, 2005), using the command xtabond2 in STATA 9.2 (Roodman, 2005).

\section{Data}

The data originate from the Linked Employer Employee Dataset of the IAB (LIAB), waves 1997-2004. The LIAB combines the employment statistics of the Federal Employment Agency (IABS) with establishment data from the IAB establishment panel. The employee statistics are taken from the German Employee Register (Beschäftigtenregister) which contains information on more than 98 percent of the employees in the firms from the IAB establishment panel (Alda, 2005). The advantage of this data set lies in the fact that no resorting to the subjective estimation of the respondent in the IAB establishment panel is needed and therefore measurement error is minimised. The IAB establishment panel is an annual survey of between 9,000 (in the year 1997) and 16,000 (in the year 2004) companies. ${ }^{4}$ Some questions are posed retrospectively and therefore our panel spans the period 1997-2003.

The profit variable is calculated by subtracting the expenditures for inputs and the wage sum from the turnover (all divided by the number of employees) and by subsequently taking the logs. ${ }^{5}$ Because of the lack of a variable concerning capital and

\footnotetext{
${ }^{4}$ For further information about the IAB panel see Kölling (2000).

${ }^{5}$ Profit per capita and investment per capita are added with a constant to make sure that all values are positive and hence can be logarithmised. The wage sum stems from the individual wage information in the
} 
capital costs in the panel, no capital costs can be considered in calculating profits. All variables are divided by the number of employees. This means that profits per head are explained by the apprentice share. This should reduce potential biases stemming from a positive correlation between investments and profits.

The profit per capita in a firm is explained by the shares of employees with certain qualifications. We distinguish between the groups „in apprenticeship training“, "secondary school qualification without professional degree“, "secondary school qualification with professional degree", "tertiary school qualification without professional degree, "tertiary school qualification with professional degree“, "degree from a university of applied sciences”, and a "degree from a university”. Here we take into account full-time employees only because a similar classification of qualifications is not available for part-time employees. We also include further employee characteristics such as the average tenure and age, the share of foreigners, females and parttime employees. Two indicators for industrial relations are also included: the presence of works councils and collective bargaining. Finally, it can be assumed that investments per employee and export share are correlated with profits.

The variable "in apprenticeship training“ also includes volunteers, interns, apprentices in full-time schools (e.g. in the healthcare sector), as well as participants in vocational training and initial training. Therefore, interns and volunteers with still not established career are excluded from the information on "performed activity". Furthermore, an alternative variable from social assistance notification (DEÜV Meldung) is generated, that explicitly excludes interns, working students, and short-term employees. In both variables the shares of apprentices are with around $8 \%$ of the work force slightly higher than in comparable data sets, partly because they include apprentices in full-time schools and employees participating in vocational training. As a robustness check also the information on the share of apprentices from the IAB establishment panel are used. All three indicators for the share of apprentices lead to practically the same results and therefore only the results on the basis of the social assistance notification are presented (compare table 1).

employment register. It is censored at the social security insurance level. For the censored wage regressions, we use an imputation procedure analogously to that in Addison et al., 2006. 


\section{Findings}

The pooled profit estimation in table 2 shows that the share of apprentices is significantly negatively correlated with profits. In addition, higher investments per capita, the presence of works councils, collective bargaining, and the export share are positively correlated with profits. The share of employees with a lower than tertiary qualification has a negative correlation, while the share of employees with a higher qualification is positively correlated with profits. The share of foreigners and parttime employees is positively correlated with profits while the share of female employees is negatively correlated.

The pooled regression is possibly biased because observations of the same firm in different years are considered as independent and unobserved heterogeneity cannot be taken into account. The Fixed Effects Regression in table 3 shows, correspondingly, a smaller number of significant coefficients. Higher investments per capita and a higher share of parttime employees still correlate positively with higher profits per capita. The share of apprentices is now insignificant while still lower qualified employees have a negative and higher qualified employees have a positive correlation with profits. Average tenure is now negatively correlated with profits. Please note that we had to exclude all time invariant variables in the fixed effects estimation.

The endogeneity problem is tackled in the system GMM regressions. Here, the lagged endogenous variable is added and instrumented. Investment per capita is regarded as a potentially predetermined variable, the dummies for industry, time, and firm size are assumed to be exogenous. The remaining variables are potentially endogenous. The lagged endogenous variable has a significantly positive impact on profit per capita (compare table 4). Both, the lagged share of apprentices and the contemporary share of apprentices have a positive albeit insignificant impact on profits. These results of our preferred estimation specification comply with results from Switzerland that a majority of firms is not ready to bear net costs during the apprenticeship training (Wolter et al., 2006). They are in contrast, however, to German studies based on direct costs and benefits surveys that indicate that in all apprenticeship professions firms incur net costs during the apprenticeship training period (compare von Bardeleben et al., 1995; Beicht et al., 2004). While the contemporary shares of secondary education without and with professional degree and the share of a university degree have a negative impact on 
profits, their lagged values are positive. According to our theoretical hypotheses the contemporaneous share of investments has a positive impact on profits per capita. The share of parttime employees as well as the share of foreigners has a positive impact on profits. The presence of works councils has a positive, the location in East Germany a negative impact on profits. The estimation diagnostics indicate that our preferred estimation specification is acceptable: The Hansen-Test does not indicate overidentification while the Arellano-Bond test does not indicate AR(2).

\section{Conclusions}

This paper examines for the first time the impact of apprenticeship training intensity on firms' profits in the same and in the next year for Germany. The data basis is the representative linked employer-employee panel data set of the IAB (LIAB). This has the advantage that crucial variables such as the wage sum, the qualification shares and the share of apprentices in an establishment stem from administrative data and they are therefore measured with a comparatively low measurement error.

The main question this paper tries to answer is whether German establishments accept net costs during the training period or whether they try to recuperate these costs with the apprentice's productivity already during the training period (i.e. they are productivity oriented). The motivation for this exercise is the notion that if German establishments would invest more in apprenticeship training, the current gap in apprenticeship offers could probably be reduced. Our preferred estimation version shows that on average an increase in the share of apprentices has no impact on establishment profits in the same year and a year later. We might interpret this as an indication that the majority of German firms does not pay more for the apprentices than their productivity during the apprenticeship period. This finding is similar to results from Switzerland.

In order to identify which firms pay more than the productivity during the apprenticeship training and which professions lead to net costs or returns during the apprenticeship period there are several natural extensions to the present approach. On the one hand differences in the profit impact of training intensities for several groups of establishments (for example those with and without works councils, establishments in a certain sector, size bracket, region etc.) should be analysed. On the other hand the share 
of different professions that have different net costs during apprenticeships (compare Schweri et al., 2003 or Beicht et al., 2004) should be taken into account. 


\section{Literature}

Abel, A. B. and Blanchard, O. J. (1986), The Present Value of Profits and Cyclical Movements in Investment, Econometrica 54(2): 249-73.

Acemoglu, D. and J.-S. Pischke (1998), Why do Firms Train? Theory and Evidence, Quarterly Journal of Economics 113: 79-119.

Acemoglu, D. and J.-S. Pischke (1999a), Beyond Becker: Training in Imperfect Labour Markets, Economic Journal 109: 112-142.

Acemoglu, D. and J.-S. Pischke, (1999b), The structure of wages and investment in general training, Journal of Political Economy 107: 539-72.

Addison, J., C. Schnabel and J. Wagner (2004), The Course of Research into the Economic Consequences of German Works Councils, British Journal of Industrial Relations 42: 255-281.

Addison, J., P. Teixera, T. Zwick (2006), The Impact of Wage Councils on Wages, ZEW Discussion Paper 06-086, Mannheim.

Alda, H. (2005), Datenbeschreibung der Version 1.1 des LIAB Querschnittmodells, FDZ Datenreport 2/2005, Nürnberg.

Arellano, M. and O. Bover (1995) Another Look at the Instrumental Variable Estimation of Error-Components Models, Journal of Econometrics 68: 29-51.

Backes-Gellner, U. (1992), Berufsbildungssysteme und die Logik betrieblicher Qualifizierungsstrategien im internationalen Vergleich. Gibt es einen "Wettbewerb der Systeme"?, in: Boettcher, E. et al. (eds.), Jahrbuch für Neue Politische Ökonomie, Tübingen. 
Backes-Gellner, U. (1995), Die institutionelle Bedingtheit betrieblicher Qualifizierungsstrategien. Ein Vergleich der Berufsausbildung in Deutschland und Großbritannien, in: Semlinger, K./Frick, B. (eds.), Betriebliche Modernisierung in personeller Erneuerung: Personalentwicklung, Personalaustausch und betriebliche Fluktuation, Berlin.

Bardeleben, R. von, U. Beicht, and K. Fehér (1995), Betriebliche Kosten und Nutzen der Ausbildung: repräsentative Ergebnisse aus Industrie, Handel und Handwerk, Bertelsmann: Bielefeld.

Becker, G. S. (1964), Human Capital. A Theoretical and Empirical Analysis, with Special Reference to Education, Basic Books: New York/London.

Beicht, U, G. Walden, and H. Herget (2004), Kosten und Nutzen der betrieblichen Berufsausbildung in Deutschland, Bertelsmann: Bielefeld.

Berthold, N. and R. Fehn (1998), Die zehn Gebote der Arbeitsmarktpolitik, Wirtschaftswissenschaftliche Beiträge des Lehrstuhls für Volkswirtschaftslehre, Wirtschaftsordnung und Sozialpolitik, Bayerische Julius-Maximilians-Universität Würzburg, Nr. 21.

Blundell, R. and S. Bond (1998), Initial Conditions and Moment Restrictions in Dynamic Panel Data Models, Journal of Econometrics 87: 115-143.

Booth, A. L. and G. Zoega (2000), Is wage compression a necessary condition for firmfinanced general training? - A Comment on Acemoglu and Pischke, Discussion Paper No. 2/00 Birkbeck College, University of London.

Dustmann, C. and U. Schönberg (2004): Training and Union Wages, IZA Discussion Paper 1435, Bonn.

Elbaum, B. and N. Singh. (1995), “The economic rationale of apprenticeship training: some lessons from British and U.S. experience”, Industrial Relations 34: 593-622. 
Ericsson, T. (2005), Personnel training: a theoretical and empirical review. IFAU Working Paper 2005/1.

Euwals, R. and R. Winkelmann (2001), Why do Firms Train? Empirical Evidence on the First Labour Market Outcomes of Graduated Apprentices, IZA Discussion Paper 319, Bonn.

Fletcher, R. (2001), A Holistic Approach to Internationalization, International Business Review 10: 25-49.

Franz, W. and D. Soskice (1995), “The German Apprenticeship System”, in F. Buttler, W. Franz, R. Schettkat and D. Soskice (eds.): Institutional Frameworks and Labor Market Performance, Routledge, London: 208-34.

Carmichael, H. L. (1989), Self-Enforcing Contracts, Shirking, and Life Cycle Incentives, The Journal of Economic Perspectives 3: 65-83.

Chang, C., and Y. Wang (1996), Human Capital Investment under Asymmetric Information: The Pigovian Conjecture Revisited, Journal of Labor Economics 16: 505519.

FitzRoy, F. R. and K. Kraft. (1985), “Unionization, Wages and Efficiency - Theories and Evidence from the U.S. and West Germany.” Kyklos 38: 537-554.

Fougère, D. and W. Schwerdt (2002), Are Apprentices Productive? Konjunkturpolitik 48: 317-346.

Harhoff, D. and T. J. Kane (1997), Is the German Apprenticeship System a

Panacea for the U. S. Labor Market? Journal of Population Economics 10: 171-196.

Freeman, R. B. and E. P. Lazear (1995), “An Economic Analysis of Works Councils.” In Joel Rogers and Wolfgang Streeck (eds.), Works Councils: Consultation, Representation, 
and Cooperation in Industrial Relations. Chicago, IL: University of Chicago Press: 2750.

Gale, B. (1972), Market Share and Rate of Return, Review of Economics and Statistics 54: 412-23.

Galindo-Rueda, F. and J. Haskel (2005), Skills, Workforce Characteristics and FirmLevel Productivity: Evidence from the Matched ABI/Employer Skills Survey, IZA Discussion Paper 1542, Bonn.

Galor, O. and O. Moav (2003), From Physical to Human Capital Accumulation: Inequality and the Process of Development, [www.restud.org.uk/PDF/8048.pdf]

Gartner, H. and G. Stephan (2004), How Collective Contracts and Works Councils Reduce the Gender Wage Gap, IAB Discussion Paper 7/2004, Nuremberg.

Hansjosten, H. (2000), Lohnt sich die betriebliche Ausbildung? - Eine Studie am Beispiel der DaimlerChrysler AG, Rainer Hampp Verlag, München/Mering.

Harhoff, D. and T. Kane. (1997), "Is the German apprenticeship system a panacea of the U.S. labor market?”, Journal of Population Economics 10: 171-96.

Hellerstein, J., D. Neumark and K. Troske (1999), Wages, Productivity, and Worker Characteristics: Evidence from Plant-Level Production Functions and Wage Equations, Journal of Labor Economics 17: 409- 446.

Hempell, T. (2006), Computer and Productivity, ZEW Economic Studies 33, Heidelberg. Institut der deutschen Wirtschaft (2006), Deutschland in Zahlen, Köln.

Katz, E., and A. Ziderman (1990), Investment in General Training: The Role of Information and Labour Mobility, Economic Journal 100: 1147-1158. 
Kölling, A. (2000), The IAB Establishment Panel, Schmollers Jahrbuch 120: 291-300.

Kölling, A. (2002), Fachkräftebedarf als betriebliches Matching-Problem, Mitteilungen aus der Arbeitsmarkt- und Berufsforschung 35: 566-579.

Lazear, E. P. (1981), Agency, Earnings Profiles, Productivity, and Hours Restrictions, The American Economic Review 71: 606-620.

Lindley, R. M. (1975), The Demand for Apprentice Recruits by the Engineering Industry: 1951-1971, Scottish Journal of Political Economy 22: 1-24.

Neubäumer, R. (1999), Der Ausbildungsstellenmarkt der Bundesrepublik Deutschland: Eine theoretische und empirische Analyse, Berlin.

Niederalt, M., C. Schnabel and C. Kaiser (2001), Betriebliches Ausbildungsverhalten zwischen Kosten-Nutzen-Kalkül und gesellschaftlicher Verantwortung - Einflussfaktoren der Ausbildungsintensität von deutschen Betrieben, Diskussionspapier No.7, FriedrichAlexander-Universität Erlangen-Nürnberg.

Roodman, D. (2006), How to Do xtabond2: An Introduction to "Difference" and "System" GMM in Stata, Center for Global Development Working Paper 103, Washington D.C..

Sadowski, D. (1980), Berufliche Bildung und betriebliches Bildungsbudget, Stuttgart.

Schwerdt, W., and S. Bender (2003), Was tun Lehrlinge nach ihrer Ausbildung? Eine Analyse mit dem Linked Employer-Employee-Datensatz des IAB. Mitteilungen aus der Arbeitsmarkt- und Berufsforschung 36: 46-59.

Schweri, J., S. Mühlemann, Y. Pescio, B. Walther, S. C. Wolter and L. Zürcher (2003), Kosten und Nutzen der Lehrlingsausbildung aus der Sicht Schweizer Betriebe, Beiträge zur Bildungsökonomie, Band 2, Verlag Rüegger: Zürich / Chur. 
Smits, W. and T. Zwick (2004), Why Do Business Service Firms Employ Fewer Apprentices? A Comparison between Germany and the Netherlands, International Journal of Manpower, 25: 36-54.

Smits, W. and T. Stromback (2001), The Economics of the Apprenticeship System, Cheltenham/Northampton, Edward Elgar.

Stalder, E. B. (1999), Warum Lehrlinge ausbilden? Ausbildungsbereitschaft, Lehrstellenangebot und Bildungsreformen aus der Sicht von Lehrbetrieben des Kantons Bern, Bern: Abteilung Bildungsplanung der Erziehungsdirektion.

Stevens, M. (2004), A Theoretical Model of On-the-Job Training with Imperfect Competition, Oxford Economics Papers 46: 537-562.

Windmeijer, F. (2005), A Finite Sample Correction for the Variance of Linear Efficient Two-Step GMM Estimators, Journal of Econometrics 126: 25-51.

Wolter, S., S. Mühlemann, and J. Schweri (2006), Why Some Firms Train Apprentices and Many Others Do Not, German Economic Review 7: 249- 264.

Zimmermann, K. F. (1998), Immigration und Arbeitsmarkt: Eine ökonomische Perspektive, in: Boesler, K.-A./Heinritz, G./Wiessner, R. (eds.), Europa zwischen Integration und Regionalismus, Stuttgart: 56-66.

Zwick, T. (2001), Beschäftigungsmöglichkeiten von Fachkräften mit Dualer Ausbildung in informationsintensiven Dienstleistungsunternehmen, Mitteilungen aus der Arbeitsmarkt- und Berufsforschung 34: 74-81

Zwick, T. (2004a), Weiterbildungsintensität und betriebliche Produktivität, Zeitschrift für Betriebswirtschaft 74: 651-668. 
Zwick, T. (2004b), Employee participation and productivity, Labour Economics 11: 715740.

\section{Tables}

Table 1: Descriptive statistics

\begin{tabular}{|c|c|c|}
\hline Variables & $\begin{array}{l}\text { Number of } \\
\text { observations }\end{array}$ & Averages \\
\hline Profit per employee in $€(\log )$ & 27007 & 11.95 \\
\hline Number of employees & 47476 & 183.04 \\
\hline Investment per employee in $€$ (log) & 31048 & 6.87 \\
\hline Share apprentices & 47640 & 0.08 \\
\hline $\begin{array}{l}\text { Share employees with secondary education, without } \\
\text { professional degree }\end{array}$ & 47640 & 0.15 \\
\hline $\begin{array}{l}\text { Share employees with secondary education, with } \\
\text { professional degree }\end{array}$ & 47640 & 0.62 \\
\hline $\begin{array}{l}\text { Share employees with tertiary education, without } \\
\text { professional degree }\end{array}$ & 47640 & 0.01 \\
\hline $\begin{array}{l}\text { Share employees with tertiary education, with professional } \\
\text { degree }\end{array}$ & 47640 & 0.03 \\
\hline Polytechnics degree & 47640 & 0.03 \\
\hline University degree & 47640 & 0.05 \\
\hline Average tenure in days & 47637 & 1946.41 \\
\hline Average age & 47640 & 38.81 \\
\hline Share exports & 32314 & 7.82 \\
\hline Share females & 47640 & 0.36 \\
\hline Share foreigners & 47640 & 0.05 \\
\hline Share parttime employees & 47640 & 0.13 \\
\hline Collective bargaining & 47640 & 0.75 \\
\hline Works council & 47265 & 0.41 \\
\hline East Germany & 47640 & 0.42 \\
\hline
\end{tabular}

Source: LIAB, waves 1997 - 2004, own calculations. 
Table 2: Pooled Regression, dependent variable: profit per employee

\begin{tabular}{|c|c|c|}
\hline Variable & Coefficient & Standard deviation \\
\hline Investment per employee & $0.017 * * *$ & 0.001 \\
\hline Share apprentices & $-0.194 * * *$ & 0.025 \\
\hline Works council & $0.091 * * *$ & 0.005 \\
\hline $\begin{array}{l}\text { Share employees with secondary } \\
\text { education, without professional } \\
\text { degree }\end{array}$ & $-0.084 * * *$ & 0.014 \\
\hline $\begin{array}{l}\text { Share employees with secondary } \\
\text { education, with professional degree }\end{array}$ & $-0.045^{* * *}$ & 0.009 \\
\hline $\begin{array}{l}\text { Share employees with tertiary } \\
\text { education, with professional degree }\end{array}$ & $0.380 * * *$ & 0.047 \\
\hline Polytechnics degree & $0.262 * * *$ & 0.036 \\
\hline University degree & $0.117 * * *$ & 0.029 \\
\hline Average tenure & 0.002 & 0.001 \\
\hline Average age & 0.015 & 0.019 \\
\hline Share exports & $0.050 * * *$ & 0.005 \\
\hline Share foreigners & $0.083 * * *$ & 0.022 \\
\hline Collective bargaining & $0.041^{* * *}$ & 0.004 \\
\hline Share females & $-0.038 * * *$ & 0.009 \\
\hline Share parttime employees & $0.288 * * *$ & 0.019 \\
\hline Constant & $11,699 * * *$ & 0.069 \\
\hline Number of observations & \multicolumn{2}{|c|}{22,590} \\
\hline Adjusted $\mathrm{R}^{2}$ & \multicolumn{2}{|c|}{0.1267} \\
\hline F $(15,22590)$ (Probability F>0) & \multicolumn{2}{|c|}{$210.92(0,00)$} \\
\hline
\end{tabular}

Source: LIAB, Waves 1997 - 2004, own calculations.

Notes: Significance levels: $*<0,1 ; * *<0,05 ; * * *<0,01$, reference value for qualification shares: tertiary education without professional degree. 
Table 3: Fixed effects regression, dependent variable: profits per employee

\begin{tabular}{|c|c|c|}
\hline Variables & Coefficients & Standard deviation \\
\hline Investment per employee & $0.003 * * *$ & 0.001 \\
\hline Share apprentices & -0.0005 & 0.039 \\
\hline $\begin{array}{l}\text { Share employees with secondary } \\
\text { education, without professional } \\
\text { degree }\end{array}$ & -0.031 & 0.035 \\
\hline $\begin{array}{l}\text { Share employees with secondary } \\
\text { education, with professional degree }\end{array}$ & $-0.041 *$ & 0.024 \\
\hline $\begin{array}{l}\text { Share employees with tertiary } \\
\text { education, with professional degree }\end{array}$ & $0.133^{*}$ & 0.057 \\
\hline Polytechnics degree & -0.009 & 0.060 \\
\hline University degree & $0.110^{*}$ & 0.059 \\
\hline Average tenure & $-0.001^{*}$ & 0.0004 \\
\hline Average age & 0.011 & 0.032 \\
\hline Share exports & -0.006 & 0.007 \\
\hline Share foreigners & 0.044 & 0.050 \\
\hline Share females & 0.007 & 0.021 \\
\hline Share parttime employees & $0.494 * * *$ & 0.020 \\
\hline Constant & $11.805^{* * *}$ & 0.121 \\
\hline Number of observations (firms) & \multicolumn{2}{|c|}{$22,757(9,130)$} \\
\hline F(13,13614) (Probability F>0) & \multicolumn{2}{|c|}{$54.08(0.00)$} \\
\hline
\end{tabular}

Source: LIAB, Waves $1997-2004$, own calculations.

Notes: Significance levels: $*<0,1 ; * *<0,05 ; * * *<0,01$, reference value for qualification shares: tertiary education without professional degree. 
Table 4: Two-step dynamic panel system GMM regression, dep. var.: profits per employee

\begin{tabular}{|c|c|c|}
\hline Variables & Coeff. & Standard deviation \\
\hline \multicolumn{3}{|l|}{ Profits per employee } \\
\hline L1 & $0.272 * * *$ & 0.048 \\
\hline Investments per employee & $0.003^{* *}$ & 0.001 \\
\hline L1 & 0.000 & 0.001 \\
\hline Share apprentices & 0.085 & 0.197 \\
\hline L1 & 0.121 & 0.137 \\
\hline Share secondary education without professional degree & $-0.410 * *$ & 0.179 \\
\hline L1 & $0.278^{*}$ & 0.154 \\
\hline Share secondary education with professional degree & $-0.235 * *$ & 0.103 \\
\hline L1 & $0.226 * *$ & 0.088 \\
\hline Share tertiary education with professional degree & -0.060 & 0.273 \\
\hline L1 & 0.243 & 0.266 \\
\hline Share polytechnics degree & 0.082 & 0.300 \\
\hline L1 & 0.017 & 0.196 \\
\hline Share university degree & $-0.633^{*}$ & 0.330 \\
\hline L1 & $0.779 * * *$ & 0.285 \\
\hline Average tenure & 0.059 & 0.043 \\
\hline L1 & -0.038 & 0.033 \\
\hline Average age & -0.210 & 0.192 \\
\hline L1 & 0.218 & 0.134 \\
\hline Share exports & 0.017 & 0.046 \\
\hline L1 & 0.012 & 0.020 \\
\hline Share foreigners & $0.372 * *$ & 0.170 \\
\hline L1 & -0.162 & 0.157 \\
\hline Share females & 0.095 & 0.098 \\
\hline L1 & -0.056 & 0.060 \\
\hline Share parttime employees & $0.202^{*}$ & 0.111 \\
\hline L1 & $-0.138 * *$ & 0.055 \\
\hline Works council & $0.053^{* * *}$ & 0.012 \\
\hline Collective bargaining & 0.008 & 0.006 \\
\hline East Germany & $-0.072 * * *$ & 0.019 \\
\hline Constant & $8.541^{* * *}$ & 0.837 \\
\hline
\end{tabular}

Number observations (establishments)

$\mathrm{F}(53,5151)$ (Probability F $>0)$

$12,264(5,152)$

Hansen Test on overidentification (Probability $>\chi 2$ )

Arellano-Bond Test for AR(1) in first differences $(\operatorname{Pr}>\mathrm{z})$

$36.24(0.00)$

Arellano-Bond Test for AR(2) in first differences $(\operatorname{Pr}>\mathrm{z})$

$$
\begin{gathered}
\chi 2(259)=252.96(0.594) \\
z=-7.87(0.00) \\
z=1.23(0.217)
\end{gathered}
$$

Source: LIAB, Waves $1997-2004$, own calculations.

Comments: Significance levels: $*<0,1 ; * *<0,05 ; * * *<0,01$. L1 means lag by 1 year, reference value for qualification shares: tertiary education without professional degree, additional variables: year dummies, 16 sector dummies, 3 establishment size dummies. 


\section{Appendix}

Figure A1 Supply of and demand for apprenticeship positions in West Germany

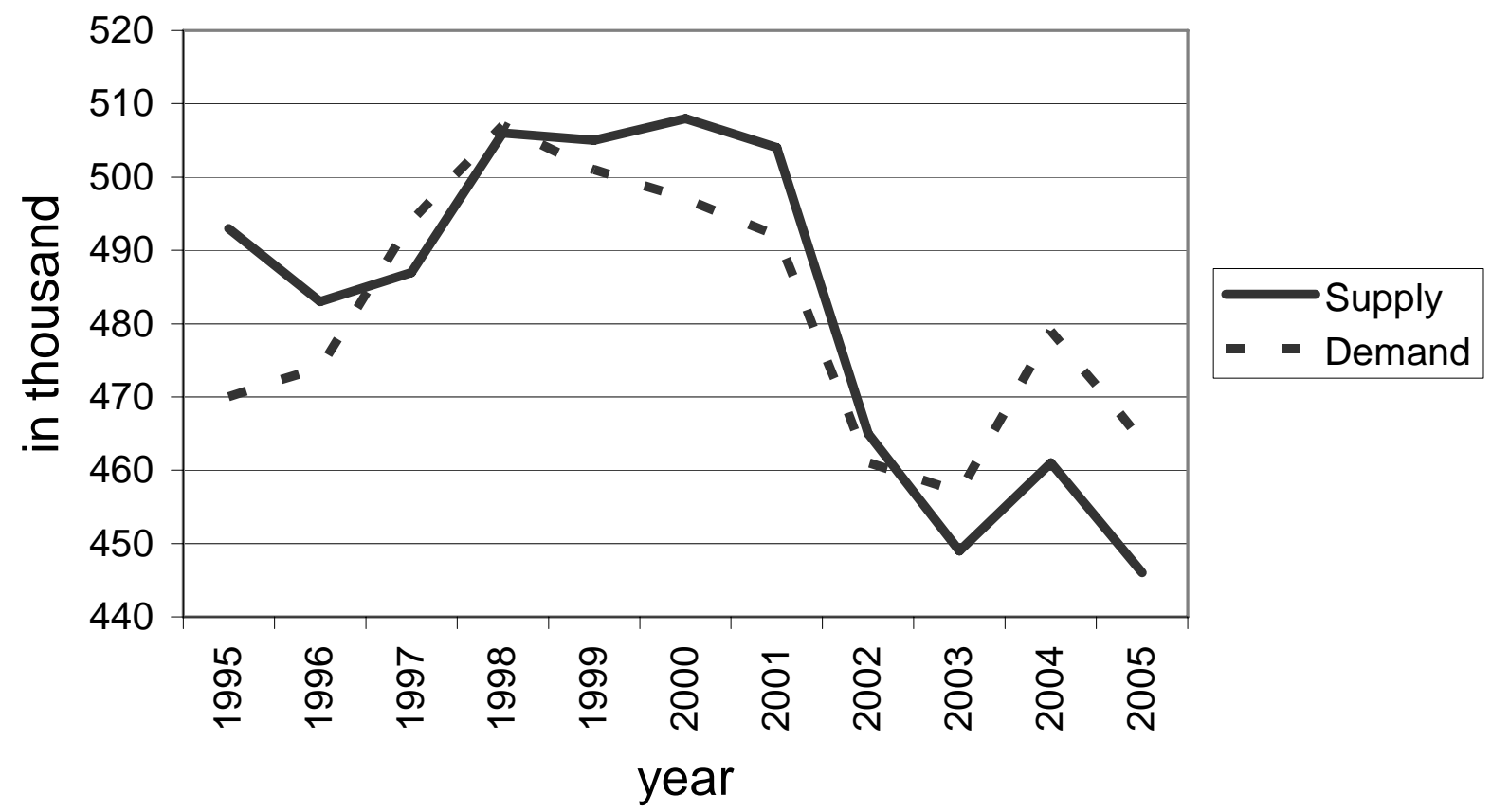

Source: Institut der deutschen Wirtschaft (2006), own illustration 
Figure A2 Supply of and demand for apprenticeship positions in East Germany

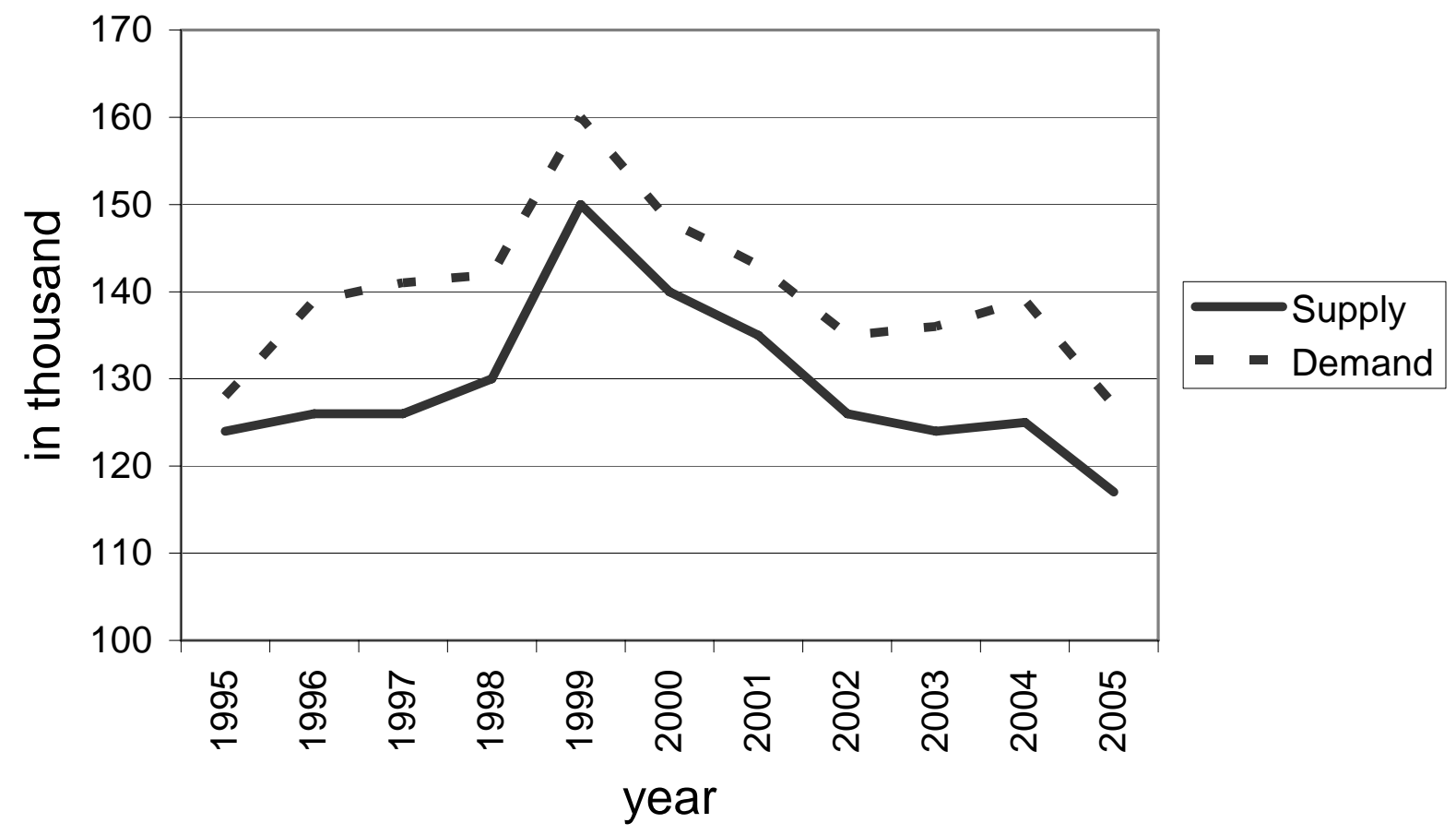

Source: Institut der deutschen Wirtschaft (2006), own illustration 